\title{
Hepatitis Be antigen and antibody in hepatitis B surface antigen positive blood donors
}

\author{
A. BARR ${ }^{1}$, S. H. BLACK ${ }^{2}$, C. J. BURRELL ${ }^{2}$, B. DOW 1 , AND I. MACVARISH \\ From the ${ }^{1}$ Glasgow and West of Scotland Regional Transfusion Centre, Law Hospital, Carluke, \\ Lanarkshire, and the ${ }^{2}$ Hepatitis Reference Laboratory, Department of Bacteriology, Edinburgh Medical \\ School, Edinburgh, UK
}

SUMMARY In a study of 105 asymptomatic HBsAg positive blood donors, $9(8.6 \%)$ were found to have $\mathrm{HBeAg}, 38(36.2 \%)$ anti-HBe, and the remaining $58(55.2 \%)$ neither marker detectable by gel diffusion. There was no correlation between $\mathrm{HBeAg} /$ anti-HBe status and HBsAg sub-types, Glm allotypes, the presence of anti-Gm, red cell antibodies, or rheumatoid factor. Rheumatoid factor activity could be removed from anti-HBe positive sera without removing anti-HBe activity, indicating that separate entities were involved.

HBeAg was found only in donors under the age of $30(\mathrm{P}<0.005)$, while anti-HBe did not show an age-related trend. HBeAg was also found less commonly in donors of blood group $A$ than in the total carrier population $(P<0.05)$, indicating an apparent protection in carriers of group $A$. The blood group distribution for the $105 \mathrm{HBsAg}$ positive donors was similar to that of the general population.

The possibility that the host genetic make-up may influence the type of response to human hepatitis B infection has led to a search for allotypic markers linked to certain types of response. For example, evidence has been presented for (Arndt-Hanser et al., 1974) and against (Rundle et al., 1975) an association between specific ABO blood groups and persistent hepatitis B surface antigen ( $\mathrm{HBsAg}$ ) carriage. In multiply transfused thalassaemic patients, Blumberg et al. (1972) described an association between the development of anti-HBs (that is, successful virus elimination) and the presence of both anti-Gm antibodies and relative homozygosity with respect to $\mathrm{Gm}$ immunoglobulin markers. Hillis et al. (1977) have reported a positive association between certain locus B HLA types and HBs antigenaemia in dialysis patients. Finally, it has been proposed that a tendency to HBsAg carriage after hepatitis B virus (HBV) infection may be inherited as a simple autosomal recessive gene (Blumberg et al., 1969), although convincing evidence against this hypothesis in its simplest form has been presented (Vyas, 1974; Mazzur, 1976).

Among chronic carriers of HBsAg, the additional presence of $\mathrm{HBeAg}$ (Magnius and Espmark, 1972) is

Received for publication 7 August 1978 associated with a greater likelihood of infectivity and progressive liver damage. Early in acute hepatitis B infection $\mathrm{HBeAg}$ can usually be detected, to be replaced later by anti-HBe in a majority of cases (Frösner et al., 1978; Miyakawa and Mayumi, 1978); the persistence of $\mathrm{HBeAg}$ indicates a more serious prognosis. Thus the presence of $\mathrm{HBeAg}$ or anti-HBe in HBsAg carriers allows an additional serological distinction between different clinical responses to HBV infection, which might show a clear relationship to the above allotypic markers.

In addition, evidence was presented by Neurath and Strick (1977) that HBeAg itself may be an idiotypic IgG molecule and anti-HBe an anti-idiotype. However, more recent work (Takahashi et al., 1978) has shown that $\mathrm{HBeAg}$ activity can exist in serum as a molecule smaller than IgG, as well as in association with IgG. Nevertheless, the possibility that the $\mathrm{HBeAg} /$ anti-HBe system might be associated with the $\mathrm{Gm}$ system, or with naturally occurring rheumatoid factor, warranted investigation.

In this paper we have examined the $\mathrm{HBeAg} /$ anti$\mathrm{HBe}$ status of 105 asymptomatic $\mathrm{HBs} A \mathrm{~g}$ positive blood donors detected at routine screening and correlated our findings with age, ABO and Rhesus (D) blood groups, HBsAg subtype, Glm allotype, the presence or absence of rheumatoid factor, anti-Gm, and red cell antibodies. 


\section{Methods}

HBsAg was detected by reverse passive haemagglutination (RPHA, Wellcome) or radioimmunoassay (RIA, Abbott). Five of the 105 donors were positive by RIA but negative by RPHA. HBeAg and anti-HBe were detected by gel diffusion after threefold concentration of test sera; all positive results gave a line of identity with a positive control reaction, and gave no precipitin lines with negative control sera of groups $A B$ and $O$. Sera were tested for rheumatoid factor (RF) using different commercial kits by latex agglutination and a modified Waaler-Rose procedure (Searle, Hyland and Denver) in the two laboratories and discrepant results were re-tested. HBsAg subtyping was performed using solid phase radioimmunoassay and by radioimmunoprecipitation using monospecific antisera. Glm(a) and $\operatorname{Glm}(f)$ allotyping was performed by a passive haemagglutination inhibition technique (Vyas et al., 1968) using red cells coated with anti$\mathrm{Rh}$ of appropriate Glm allotype. The screening for anti-Gm was carried out using a panel of cells coated with various anti-Rh sera known to detect most anti-Gm antibodies (M. M. Izatt, personal communication).

\section{Results}

$\mathrm{HBeAg}$ was found in $9(8.6 \%)$ sera and anti-HBe in $38(36.2 \%)$, while $58(55.2 \%)$ sera showed neither reaction. Blood group $\mathrm{A}$ was less common $(\mathrm{P}<0.05)$ in $\mathrm{HBeAg}$ positive donors than in the total carrier population, which itself showed $\mathrm{ABO}$ and Rhesus(D) blood group frequencies similar to those of the overall regional population (Table 1 ).

Table 1 Distribution of $A B O$ and Rhesus $(D)$ blood groups in relation to the $\mathrm{HBeAg/anti-HBe}$ status of 105 carriers of $\mathrm{HBSAg}$

\begin{tabular}{llrrr}
\hline Group & HBeAg & anti-HBe & Neither & Total \\
\hline O & 8 & 19 & 31 & 58 \\
A & 0 & 14 & 20 & 34 \\
B & 1 & 2 & 5 & 8 \\
AB & 0 & 3 & 2 & 5 \\
Rh(D) positive & 9 & 31 & 52 & 92 \\
Rh(D) negative & 0 & 7 & 6 & 13 \\
Total & 9 & 38 & 58 & 105 \\
\hline
\end{tabular}

The percentage of carriers with $\mathrm{HBeAg}$ declined with age, whereas no age-specific trend was seen in anti-HBe frequency (Figure). All nine $\mathrm{HBeAg}$ positive carriers were less than 30 years of age, while 57 of the total group of 105 were aged less than 30 $(P<0.005)$. No age specific trend in blood group distribution was present, indicating that age and blood group were independently correlated with $\mathrm{HBeAg}$ distribution.

No correlation was seen between the presence or absence of rheumatoid factor and the presence of $\mathrm{HBeAg}$ or anti-HBe (Table 2). Similar conclusions have been made in other studies of healthy blood donors (Tedder and Briggs, 1977; Furuta et al., 1977), although an association between RF and antiHBe was reported in one study (Kacaki et al., 1977). To examine formally the possibility that anti-HBe and RF recognised the same determinants on IgG molecules and were functionally identical, RF activity was removed from RF positive, anti-HBe positive sera by caprylic acid treatment or absorption with $5 \mathrm{mg} / \mathrm{ml}$ of denatured $\left(75^{\circ} \mathrm{C}\right.$ for $\left.15 \mathrm{~min}\right)$ pooled human gammaglobulin. Both treatments removed all detectable RF activity, while the reconcentrated treated sera contained anti-HBe in $2 / 2$ sera after absorption with globulin, and in $1 / 3$ sera after treatment with caprylic acid. These results provided further evidence that RF and anti-HBe activity were not related.

Table 2 Distribution of rheumatoid factor $(R F)$ in relation to $\mathrm{HBeAg} /$ anti-HBe status of 105 carriers $o$ $\mathrm{HBSAg}$

\begin{tabular}{llcc}
\hline & RF positive & RF negative & Total \\
\hline HBeAg & 0 & 9 & 9 \\
Anti-HBe & 4 & 34 & 38 \\
Neither & 6 & 52 & 58 \\
Total & 10 & 95 & 105 \\
\hline
\end{tabular}

The Glm allotype frequencies among all HBsAg carriers were similar to those for the region as a whole, and no relationship was seen between Glm allotype and $\mathrm{HBeAg} /$ anti-HBe status or the presence of RF (Table 3). Similarly, the presence of anti-Gm or red cell antibodies was not correlated with $\mathrm{HBeAg}$ / anti-HBe status.

The HBsAg subtype composition of the sera is also shown in Table 3. No association existed between either major subtype and the presence of RF or $\mathrm{HBeAg} /$ anti-HBe status of the donors. In a further analysis, no effect of age was found on the prevalence of HBsAg subtype.

Finally, as only seven of the $105 \mathrm{HBsAg}$ carriers were female it was not possible to correlate the above information in relation to the sexes.

\section{Discussion}

Radioimmunoassay increased the anti-HBe rate from $35.9 \%$ (by gel diffusion) to $88.5 \%$ in a study of 


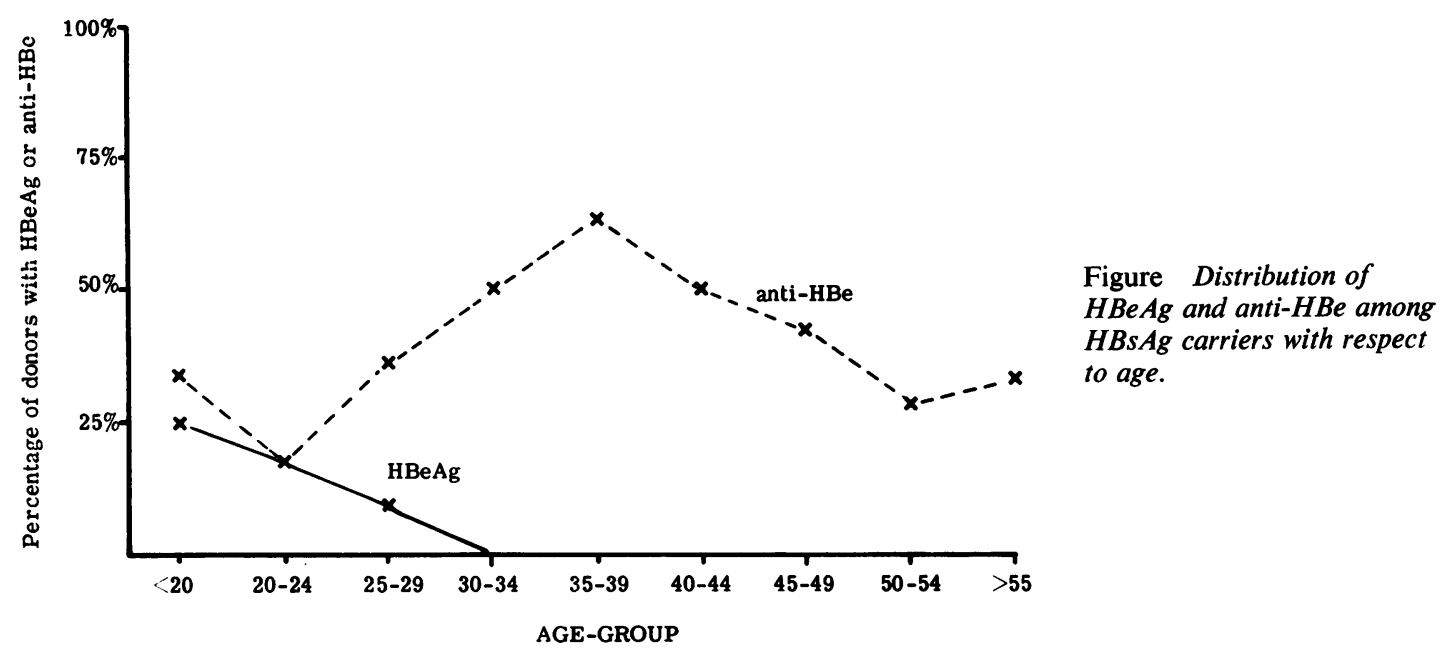

Table 3 Distribution of various markers with respect to $\mathrm{HBeAg} /$ anti-HBe and presence of rheumatoid factor

\begin{tabular}{|c|c|c|c|c|c|}
\hline & $\mathrm{HBeAg}$ & anti-HBe & $\begin{array}{l}\text { Negative for } \mathrm{HBeAg} \\
\text { and anti-HBe }\end{array}$ & $R F$ & Total \\
\hline \multicolumn{6}{|l|}{ Glm allotype } \\
\hline Glm $\mathbf{a}+\mathbf{f}-$ & 1 & 5 & 9 & 1 & 15 \\
\hline Glm $a+f+$ & 4 & 13 & 26 & 6 & 43 \\
\hline Glm a-f + & 4 & 20 & 23 & 3 & 47 \\
\hline \multicolumn{6}{|c|}{ Antibody reactivity } \\
\hline Anti-Glm & 2 & 10 & 8 & 2 & 20 \\
\hline Anti-RBC & 2 & 6 & 12 & 2 & 20 \\
\hline Neither & 5 & 22 & 38 & 6 & 65 \\
\hline \multicolumn{6}{|l|}{ HBsAg subtype } \\
\hline ad & 3 & 20 & 25 & 4 & 48 \\
\hline ay & 3 & 16 & 28 & 5 & 47 \\
\hline untyped & 3 & 2 & 5 & 1 & 10 \\
\hline Total & 9 & 38 & 58 & 10 & 105 \\
\hline
\end{tabular}

$156 \mathrm{HBsAg}$ carriers in West Germany (Biswas et al., 1978), whereas the $\mathrm{HBeAg}$ rate was increased only from $2.6 \%$ to $3.6 \%$ with the more sensitive assay. It is therefore possible that the nine $\mathrm{HBeAg}$ positive donors detected by gel diffusion in our study represent nearly all those who would be detectable by a more sensitive assay, and that the majority of donors above with neither $\mathrm{HBeAg}$ nor anti-HBe detectable would prove to have low levels of anti-HBe.

In Japanese $\mathrm{HBsAg}$ carriers, the $\mathrm{HBeAg}$ rate declined with age from $76.9 \%$ in those aged $0-9$ years to $9.5 \%$ in those aged 50 or above, while a reciprocal increase in anti-HBe rate with age was seen (Miyakawa and Mayumi, 1978). However, vertical transmission appears to play a much greater role in maintaining infection in Japan than in western Europe, introducing additional age-related factors. In a Frenchstudy of $329 \mathrm{HBs} \mathrm{Ag}$ carriers, no effect of age on the $\mathrm{HBeAg}$ rate was seen, while the anti-HBe rate declined with age (Courouce-Pauty and Plancon, 1978). As factors such as age of acquisition of infection, prevalence of various subtypes, varying transmission routes, and possible differences in life expectancy for those carriers who are $\mathrm{HBeAg}$ positive could conceivably influence $\mathrm{HBeAg} /$ antiHBe prevalence data, we cannot conclude from our age-related data that seroconversion from $\mathrm{HBeAg}$ to anti-HBe over a number of years commonly occurs in the natural history of the carrier state. In contrast, several workers have described seroconversion from $\mathrm{HBeAg}$ to anti-HBe positivity during most acute HBV infections (Frösner et al., 1978; Miyakawa and Mayumi, 1978).

An association between blood group $A$ and a lack of an $\mathrm{HBeAg}$ response has not to our knowledge been previously reported. We found no association be- 
tween $\mathrm{HBeAg} /$ anti-HBe status and $\mathrm{Glm}$ allotype or the presence of anti-Gm, red cell antibodies or rheumatoid factor. In contrast to Courouce-Pauty and Plançon (1978), we did not find a higher prevalence of $\mathrm{HBeAg}$ or anti-HBe in ad infections compared to ay infections. We were not able to compare $a d w$ and $a d r$ subtypes, which were found to be significantly different with respect to $\mathrm{HBeAg} /$ anti-HBe in the French work. We were, however, able to show that subtype distribution was not related to age in our population, a correlation that was not examined in the French study.

We are grateful to Dr J. Wallace for advice and encouragement during the course of this work, and to Miss M. M. Izatt for providing $\mathrm{Gm}$ reagents.

\section{References}

Arndt-Hañser, A., Ananthakrishan, R., and Walter, H. (1974). ABO blood groups and Australia antigen. Clinical Genetics, 5, 28-30.

Biswas, R., Gerlich, W., and Thomssen, R. (1978). Comparison of radioimmunoassay and immunodiffusion in the detection of $\mathrm{HBe} \mathrm{Ag}$ andanti-HBe. Proceedings of the Second UCSF Symposium on Viral Hepatitis, The Franklin Institute Press, Philadelphia, USA. (In press.)

Blumberg, B. S., Friedlaender, J. S., Woodside, A., Sutnick, A. I., and London, W. T. (1969). Hepatitis and Australia antigen: autosomal recessive inheritance of susceptibility to infection in humans. Proceedings of the National Academy of Sciences of the United States of America, 62, 1108-1115.

Blumberg, B. S., Vierucci, A., London, W. T., and Sutnick, A. I. (1972). Association of antibodies to Australia antigen with anti-GM antibodies in Italian patients with thalassaemia. Nature, 236, 28-30.

Courouce-Pauty, A. M., and Plançon, A. (1978). e-Antigen and anti-e in two categories of chronic carriers of hepatitis B surface antigen. Vox Sanguinis, 34, 231-238.

Frösner, G. G., Deinhardt, F. W., Overby, L. R., Papaevangelou, G., and Brodersen, M. (1978). Prevalence of $\mathrm{HBeAg}$ and anti-HBe by solid-phase radioimmunoassay in acute hepatitis B. Proceedings of the Second UCSF Symposium on Viral Hepatitis, The Franklin Institute Press, Philadelphia, USA. (In press.)
Furuta, S., Nagata, A., Kiyosawa, K., Yamamura, S., Sodeyama, K., Oda, M., and Mayumi, M. (1977). e/anti-e, rheumatoid factor, and liver disease (Letter). Lancet, 2, 353.

Hillis, W. D., Hillis, A., Bias, W. B., and Walker, W. G. (1977). Associations of hepatitis B surface antigenemia with HLA locus B specificities. New England Journal of Medicine, 296, 1310-1314.

Kacaki, J. N., Siem, T. N., and Brouwer, R. (1977). Anti-e and rheumatoid factor activity in hepatitis $\mathbf{B}$ (Letter). Lancet, 1, 1008-1009.

Magnius, L. O., and Espmark, A. (1972). A new antigen complex co-occurring with Australia antigen. Acta Pathologica Microbiologica S sandinavica, 80B, 335-337.

Mazzur, S. (1976). Genetic mimicry by hepatitis B virus. Nature, 261, 316-317.

Miyakawa, Y., and Mayumi, M. (1978). Seroconversion from $\mathrm{HBeAg}$ to anti-HBe in acute and chronic $\mathrm{HBV}$ infection. Proceedings of the Second UCSF Symposium on Viral Hepatitis, The Franklin Institute Press, Philadelphia, USA. (In press.)

Neurath, A. R., and Strick, N. (1977). Hcst specificity of a serum marker for hepatitis B: evidence that "e antigen" has the properties of an immunoglobulin. Proceedings of the National Academy of Sciences of the United States of America, 74, 1702-1706.

Rundle, A. T., Atkin, J., and Sudell, B. (1975). Hepatitis associated antigen and the ABO locus in Down's syndrome. Clinical Genetics, 8, 1-4.

Takahashi, K., Imai, M., Miyakawa, Y., Iwakiri, S., and Mayumi, M. (1978). Duality of hepatitis B e antigen in serum of persons infested with hepatitis B virus; evidence for the non identity of e antigen with immunoglobulins. Proceedings of the National Academy of Sciences of the United States of America, 75, 1952-1956.

Tedder, R. S., and Briggs, M. (1977). Anti-e and rheumatoid factor activity in hepatitis B (Letter). Lancet, 1, 1262-1263.

Vyas, G. N. (1974). Evidence against recessive inheritance of susceptibility to the chronic carrier state for hepatitis B antigen. Nature, 248, 159-160.

Vyas, G. N., Fudenberg, H. H., Pretty, H. M., and Gold, E. R. (1968). A new rapid method for genetic typing of human immunoglobulins. Journal of Immunology, 100, 274-279.

Requests for reprints to: Dr C. J. Burrell, Hepatitis Reference Laboratory, Department of Bacteriology, Edinburgh University Medical School, Teviot Place, Edinburgh EH8 9AG, UK. 